medRxiv preprint doi: https://doi.org/10.1101/2020.08.28.20180463; this version posted September 1, 2020. The copyright holder for this preprint (which was not certified by peer review) is the author/funder, who has granted medRxiv a license to display the preprint in

It is made available under a CC-BY-NC-ND 4.0 International license .

\title{
Population-based seroprevalence of SARS-CoV-2 is more than halfway through the herd immunity threshold in the State of Maranhão, Brazil
}

\section{Brief title: Seroprevalence of SARS-CoV-2 in the State of Maranhão, Brazil}

Antônio Augusto Moura da Silva ${ }^{1}$, Lídio Gonçalves Lima-Neto², Conceição de Maria Pedrozo e Silva de Azevedo ${ }^{3}$, Léa Márcia Melo da Costa ${ }^{4}$, Maylla Luana Barbosa Martins Bragança ${ }^{5}$, Allan Kardec Duailibe Barros Filho ${ }^{6}$, Bernardo Bastos Wittlin ${ }^{7}$, Bruno Feres Souza ${ }^{8}$, Bruno Luciano Carneiro Alves de Oliveira ${ }^{9}$, Carolina Abreu de Carvalho $^{10}$, Erika Barbara Abreu Fonseca Thomaz ${ }^{11}$, Eudes Alves Simões-Neto ${ }^{12}$, Jamesson Ferreira Leite Júnior ${ }^{13}$, Lécia Maria Sousa Santos Cosme ${ }^{14}$, Marcos Adriano Garcia Campos $^{15}$, Rejane Christine de Sousa Queiroz ${ }^{16}$, Sérgio Souza Costa ${ }^{17}$, Vitória Abreu de Carvalho ${ }^{18}$, Vanda Maria Ferreira Simões ${ }^{19}$, Maria Teresa Seabra Soares de Brito e Alves ${ }^{20}$, Alcione Miranda dos Santos ${ }^{21}$

* Correspondence to: Antônio Augusto Moura da Silva. Address: Postgraduate Program in Public Health. Rua Barão de Itapari, 155 - Centro, São Luís - MA, 65020-070, Brazil. E-mail: aamouradasilva@gmail.com. Telephone: +55 9832729670.

${ }^{1}$ PhD. Federal University of Maranhão, Brazil. Postgraduate Program in Public Health. Rua Barão de Itapari, 155 - Centro, São Luís - MA, 65020-070, Brazil. E-mail: aamouradasilva@gmail.com. ORCID: 0000-0003-4968-5138

${ }^{2} \mathrm{PhD}$. State Health Department of Maranhão, Maranhão, Brazil. CEUMA University, Maranhão, Brazil. Av. Prof. Carlos Cunha - Jaracaty, São Luís - MA, 65076-820. E-mail: lidio.neto@ outlook.com. ORCID: 0000-0001-7282-3047

${ }^{3} \mathrm{PhD}$. Federal University of Maranhão, Brazil. State Health Department of Maranhão, Maranhão, Brazil. Av. Prof. Carlos Cunha - Jaracaty, São Luís - MA, 65076-820. E-mail: conceicao.pedrozo@ufma.br. ORCID: 0000-0003-0712-1852

${ }^{4}$ Specialist in Public Health. State Health Department of Maranhão, Maranhão, Brazil. Av. Prof. Carlos Cunha - Jaracaty, São Luís - MA, 65076-820. E-mail: leamarciamcosta@gmail.com. ORCID: 0000-0003-0607-8506

${ }^{5}$ PhD. Federal University of Maranhão, Brazil. Postgraduate Program in Public Health. Rua Barão de Itapari, 155 - Centro, São Luís - MA, 65020-070, Brazil. E-mail: 
medRxiv preprint doi: https://doi.org/10.1101/2020.08.28.20180463; this version posted September 1, 2020. The copyright holder for this preprint (which was not certified by peer review) is the author/funder, who has granted medRxiv a license to display the preprint in

It is made available under a CC-BY-NC-ND 4.0 International license .

${ }^{6} \mathrm{PhD}$. Federal University of Maranhão, Brazil. Department of Electrical Engineering. Av. dos Portugueses, 1966 - Vila Bacanga, São Luís - MA, 65080-805, Brazil. E-mail: allan@ufma.br. ORCID: 0000-0002-1654-0955

${ }^{7}$ MD. State Health Department of Maranhão, Maranhão, Brazil. Av. Prof. Carlos Cunha - Jaracaty, São Luís - MA, 65076-820. E-mail: bernardo.bw@gmail.com. ORCID: 00000001-9791-2302

${ }^{8} \mathrm{PhD}$. Federal University of Maranhão, Brazil. Computer Engineering course. Av. dos Portugueses, 1966 - Vila Bacanga, São Luís - MA, 65080-805. E-mail: bruno.feres@ufma.br. ORCID: 0000-0003-1997-4983

${ }^{9}$ PhD. Federal University of Maranhão, Brazil. Postgraduate Program in Public Health. Rua Barão de Itapari, 155 - Centro, São Luís - MA, 65020-070, Brazil. E-mail: oliveira.bruno@ufma.br. ORCID: 0000-0001-8053-7972

${ }^{10} \mathrm{PhD}$. Federal University of Maranhão, Brazil. Postgraduate Program in Public Health. Rua Barão de Itapari, 155 - Centro, São Luís - MA, 65020-070, Brazil. E-mail: carolina.carvalho@ufma.br. ORCID: 0000-0001-7900-4642

${ }^{11} \mathrm{PhD}$. Federal University of Maranhão, Brazil. Postgraduate Program in Public Health. Rua Barão de Itapari, 155 - Centro, São Luís - MA, 65020-070, Brazil. E-mail: erika.barbara@ufma.br. ORCID: 0000-0003-4156-4067

${ }^{12}$ MD. Federal University of Maranhão, Maranhão, Brazil. State Health Department of Maranhão, Maranhão, Brazil. Av. Prof. Carlos Cunha - Jaracaty, São Luís - MA, 65076820. E-mail: eudes.simoes@ufma.br. ORCID: 0000-0001-5449-5908

${ }^{13}$ MSc. State Health Department of Maranhão, Maranhão, Brazil. Av. Prof. Carlos Cunha - Jaracaty, São Luís - MA, 65076-820. E-mail: jamessonjunior@gmail.com. ORCID: 0000-0002-8388-0044

${ }^{14}$ Specialist in Public Health. State Health Department of Maranhão, Maranhão, Brazil. Av. Prof. Carlos Cunha - Jaracaty, São Luís - MA, 65076-820. E-mail: leciacosme@uol.com.br. ORCID: 0000-0002-4630-5032

${ }^{15}$ MD. Federal University of Maranhão, Brazil. Postgraduate Program in Public Health. Rua Barão de Itapari, 155 - Centro, São Luís - MA, 65020-070, Brazil. E-mail: marcos.adrianogc@gmail.com. ORCID: 0000-0001-8924-1203

${ }^{16} \mathrm{PhD}$. Federal University of Maranhão, Brazil. Postgraduate Program in Public Health. Rua Barão de Itapari, 155 - Centro, São Luís - MA, 65020-070, Brazil. E-mail: queiroz.rejane@gmail.com. ORCID: 0000-0003-4019-2011 
medRxiv preprint doi: https://doi.org/10.1101/2020.08.28.20180463; this version posted September 1, 2020. The copyright holder for this preprint (which was not certified by peer review) is the author/funder, who has granted medRxiv a license to display the preprint in It is made available under a CC-BY-NC-ND 4.0 International license

${ }^{17}$ PhD. Federal University of Maranhão, Brazil. Computer Engineering course. Av. dos Portugueses, 1966 - Vila Bacanga, São Luís - MA, 65080-805. E-mail: sergio.costa@ufma.br. ORCID: 0000-0002-0232-4549

${ }^{18}$ Medical Student. Federal University of Maranhão, Brazil. Postgraduate Program in Public Health. Rua Barão de Itapari, 155 - Centro, São Luís - MA, 65020-070, Brazil. Email: carv.vitoria@gmail.com. ORCID: 0000-0002-7831-5761

${ }^{19} \mathrm{PhD}$. Federal University of Maranhão, Brazil. Postgraduate Program in Public Health. Rua Barão de Itapari, 155 - Centro, São Luís - MA, 65020-070, Brazil. E-mail: vanda.simoes@ufma.br. ORCID: 0000-0001-8351-1348

${ }^{20} \mathrm{PhD}$. Federal University of Maranhão, Brazil. Postgraduate Program in Public Health. Rua Barão de Itapari, 155 - Centro, São Luís - MA, 65020-070, Brazil. E-mail: mtssb.alves@ufma.br. ORCID: 0000-0002-4806-7752

${ }^{21} \mathrm{PhD}$. Federal University of Maranhão, Brazil. Postgraduate Program in Public Health. Rua Barão de Itapari, 155 - Centro, São Luís - MA, 65020-070, Brazil. E-mail: alcione.miranda@ufma.br. ORCID: 0000-0001-9711-0182 
medRxiv preprint doi: https://doi.org/10.1101/2020.08.28.20180463; this version posted September 1, 2020. The copyright holder for this preprint (which was not certified by peer review) is the author/funder, who has granted medRxiv a license to display the preprint in

It is made available under a CC-BY-NC-ND 4.0 International license .

\section{Summary}

Background: Few population-based studies on the prevalence of severe acute respiratory syndrome coronavirus 2 (SARS-CoV-2) have been performed to date, and most of them have used lateral flow immunoassays with finger-prick, which may yield false-negative results and thus underestimate the true infection rate.

Methods: A population-based household survey was performed in the State of Maranhão, Brazil, from 27 July 2020 to 8 August 2020 to estimate the seroprevalence of SARSCoV-2 using a serum testing electrochemiluminescence immunoassay. A three-stage cluster sampling stratified by four state regions was used. The estimates took clustering, stratification, and non-response into account. Qualitative detection of $\operatorname{IgM}$ and $\operatorname{IgG}$ antibodies was performed in a fully-automated Elecsys ${ }^{\circledR}$ Anti-SARS-CoV-2 electrochemiluminescence immunoassay on the Cobas ${ }^{\circledR}$ e601 analyser (Roche Diagnostics).

Findings: A total of 3156 individuals were interviewed. Seroprevalence of total antibodies against SARS-CoV-2 was 40.4\% (95\%CI 35-6-45-3). Population adherence to non-pharmaceutical interventions was higher at the beginning of the pandemic than in the last month. SARS-CoV-2 infection rates were significantly lower among mask wearers and among those who maintained social and physical distancing in the last month compared to their counterparts. Among the infected, $62.2 \%$ had more than three symptoms, $11.1 \%$ had one or two symptoms, and $26.0 \%$ were asymptomatic. The infection fatality rate was $0 \cdot 17 \%$, higher for males and advanced age groups. The ratio of estimated infections to reported cases was $22 \cdot 2$.

Interpretation: To the best of our knowledge, the seroprevalence of SARS-CoV-2 estimated in this population-based survey was the highest and the closest to the herd immunity threshold reported to date. Our results suggest that the herd immunity threshold is not as low as $20 \%$, but at least higher than or equal to around $40 \%$. The infection fatality rate was one of the lowest reported so far, and the proportion of asymptomatic cases was low. 
medRxiv preprint doi: https://doi.org/10.1101/2020.08.28.20180463; this version posted September 1, 2020. The copyright holder for this preprint (which was not certified by peer review) is the author/funder, who has granted medRxiv a license to display the preprint in

It is made available under a CC-BY-NC-ND 4.0 International license .

\section{Introduction}

Of all the countries, Brazil is one of the most severely affected by coronavirus disease 2019 (COVID-19) pandemic. Its first case was reported on 26 February 2020, and by 20 August 2020 3,501,975 cases were reported, with 112,304 deaths, the second-highest in the world. ${ }^{1}$ The national response has been controversial, testing capacity is low, and disagreements among the different levels of government over social distancing measures conveyed contradictory messages to the population. As a middle-income country, Brazil has high poverty rates and an extensive part of its population is engaged in informal activities that face difficulties to make ends meet and to follow stay-at-home measures. ${ }^{2}$ As a consequence of all these facts, social distancing has not reached levels sufficient to curb and contain the COVID-19 pandemic. $^{3}$

The State of Maranhão is located in the Northeast region of Brazil and has an estimated population of 7,114,598 inhabitants in $2020^{4}$ with an area of $329,642 \mathrm{~km}^{2}$, a little larger than that of Italy. It is one of the states in Brazil where the pandemic gathered speed early. Its first case was reported on 20 March 2020, and by 20 August 2020, the number of deaths reported was 3315. Deaths peaked in May and decreased thereafter. From 3 May 2020 to 17 May 2020 São Luís Island, where the state capital city is located, was put into lockdown. Reduction of social mobility reached at most 55\% at the end of March and during lockdown at the capital but remained low (40\%-45\%) during the worst phase of the pandemic. Despite low home quarantine adherence, the number of deaths decreased, and intensive care units occupancy diminished. ${ }^{5}$

Herd immunity to severe acute respiratory syndrome coronavirus 2 (SARS-CoV-2) is an ongoing debate. Although many consider it to be around $60 \%-70 \%$, using the classical formula $1-1 / R_{0}$, where $R_{0}$ is the basic reproductive number, ${ }^{6}$ some reports have proposed that herd immunity could be as low as $10 \%-20 \%^{7}$ or around $43 \%,{ }^{8}$ due to the heterogeneity in susceptibility or exposure to infection across population groups. ${ }^{7,8}$ However, reported population-based seroprevalences of SARS-CoV-2 were lower than the herd immunity thresholds, ranging from extremely low infections rates, close to $1 \%$ $3 \%,{ }^{9,10}$ to values as high as $14.3 \%$ in Barcelona, ${ }^{11}$ Spain, and $22 \cdot 7 \%$ in New York City. ${ }^{12}$ In Brazil, the highest reported population-based seroprevalence was $17.9 \%$, for the São Paulo municipality. ${ }^{13}$

The infection fatality rate (IFR) and the percentage of asymptomatic infections of SARSCoV-2 are known with uncertainty. Early reports at the beginning of the pandemic estimated IFR at values between $0.6 \%$ and $1.3 \%,{ }^{14,15}$ and considered asymptomatic 
medRxiv preprint doi: https://doi.org/10.1101/2020.08.28.20180463; this version posted September 1, 2020. The copyright holder for this preprint (which was not certified by peer review) is the author/funder, who has granted medRxiv a license to display the preprint in

It is made available under a CC-BY-NC-ND 4.0 International license .

infections as being highly prevalent. ${ }^{14,16}$ Most recent reviews, however, estimated a lower IFR with large variations across sites ${ }^{10,17}$ and a much lower percentage of asymptomatic infections. $^{11,18,19}$

Population-based surveys are necessary to monitor the infection progression since most cases are undocumented. ${ }^{20}$ However, few population-based studies on the prevalence of SARS-CoV-2 have been performed to date, and most of them have used lateral flow immunoassays with finger-prick, which may yield false-negative results, and thus underestimate the true infection rate. ${ }^{21,22}$ Therefore, population-based surveys using more sensitive diagnostic tests are warranted. In this population-based study, we estimated the overall seroprevalence of SARS-CoV-2 using a serum testing electrochemiluminescence immunoassay. Sociodemographic characteristics of the population, self-reported symptoms, adherence to non-pharmaceutical interventions (NPIs), use of health services, previous molecular and antibody testing among the infected, and the IFR were also assessed.

\section{Methods}

\section{Study design and participants}

A cross-sectional survey to estimate the seroprevalence of antibodies against SARS-CoV2 was conducted from 27 July 2020 to 8 August 2020 by population-based household sampling. The study was developed in cooperation between the Federal University of Maranhão and the State Health Department of Maranhão, Brazil.

Conglomerate sampling in three stratified stages in four regions was used. The regions were the Island of São Luís including the state capital, small municipalities $(<20,000$ inhabitants), medium-sized municipalities (20,000 to 100,000 inhabitants) and large municipalities except for the island (>100,000 inhabitants). In each stratum, in the first stage, 30 census tracts were selected by systematic sampling. In the second stage, 34 households were selected in each census tract by systematic sampling. In the third stage, an eligible resident (residing for at least six months in the household) aged one year or more was selected by simple random sampling using a table of random numbers.

\section{Data collection, instruments, and variables}

Trained professionals from the municipal and state health departments were responsible for data collection. Using a map provided by the Brazilian Institute of Geography and Statistics (IBGE in the Portuguese acronym) the starting point (identified with an $\mathrm{X}$ on 
medRxiv preprint doi: https://doi.org/10.1101/2020.08.28.20180463; this version posted September 1, 2020. The copyright holder for this

the map) and the geographic boundaries of each census tracts were identified. The first interview was held in the home closest to the starting point of each sector. Then, facing that domicile, the interviewer walked to the left with his/her right shoulder facing the wall/residences. Without including the visited home, the interviewer counted five residences and conducted the next interview in the fifth one. If the selected household was empty at the time or the elected person did not agree to participate in the survey, the next house to the left (neighbour) of the original one was taken as a replacement. If that house was also empty or if the elected person refused to participate the next house to the left was visited. Then the interviewer counted five domiciles and conducted the next interview in the fifth house after the original one. The team always proceeded to the left in relation to the last surveyed domicile and conducted the next interview in the fifth domicile. Non-residential buildings were excluded from the count. After completing the tour on the block, the interviewer facing the last visited domicile continued to the next adjacent block located to the left, always adopting the same strategy.

A questionnaire with closed-ended questions was applied in a face-to-face interview with the individual or his/her legal guardian. The questionnaire was composed of sociodemographic questions, adherence to NPIs, self-reported symptoms, and the use of health services. The sociodemographic questions included sex, age group, skin colour/race, head of the household's schooling, monthly family income in Brazilian Reals, and the number of the household residents. Head of the household's schooling was classified according to the International Standard Classification of Education (ISCED) 2011 into early childhood/primary/lower secondary education (levels 0-2), upper secondary/post-secondary non-tertiary education (levels 3-4), and tertiary education and beyond (levels 5-8). ${ }^{23}$ Skin colour/race was categorized according to the IBGE and divided into white, brown, or black. ${ }^{24}$ Yellows and indigenous were excluded because they were too few for a meaningful analysis.

Adherence to NPI at the beginning of the pandemic and in the last month included social distancing (yes, if the person never leaves home or seldom goes out, with a maximum of one outing every fifteen days, and no otherwise), wearing of face masks (yes, if the individual uses a mask on all exits and does not remove or seldom removes the mask from the face, and no otherwise), hand hygiene (yes, if the person sanitizes the hands more than six times per turn with soap or an alcohol gel, and no otherwise), and physical distancing (yes, if the individual never or hardly ever comes within $1.5 \mathrm{~m}$ of other people, and no otherwise). 
medRxiv preprint doi: https://doi.org/10.1101/2020.08.28.20180463; this version posted September 1, 2020. The copyright holder for this preprint (which was not certified by peer review) is the author/funder, who has granted medRxiv a license to display the preprint in

It is made available under a CC-BY-NC-ND 4.0 International license .

A self-reported symptom rating, adapted from Pollán et al. (2020), ${ }^{11}$ was used and the persons were classified into asymptomatic; oligosymptomatic: the presence of one to two symptoms without anosmia/hyposmia or ageusia/dysgeusia; and symptomatic: anosmia/hyposmia or ageusia/dysgeusia or more than two symptoms including fever, chills, sore throat, cough, dyspnoea, diarrhoea, nausea/vomiting, headache, fatigue, and myalgia.

Questions on the use of health services included if the individual looked for health services, received care when seeking health services, was hospitalized for over 24 hours, received a medical diagnosis of suspected COVID-19, performed RT-PCR for SARS$\mathrm{CoV}-2$, and performed an antibody test- point-of-care/serology for SARS-CoV-2.

Data were abstracted into the Epicollect5 Data Collection mobile application.

\section{SARS-CoV-2 antibodies detection}

For the qualitative determination of antibodies against SARS-CoV-2, 5.0 ml of whole blood was collected, and after centrifugation at $1800 \mathrm{~g}$ for $15 \mathrm{~min}$, the serum was obtained. Then, a highly sensitive and specific sandwich electrochemiluminescence immunoassay (Elecsys ${ }^{\circledR}$ Anti-SARS-CoV-2 assay, Roche Diagnostics) was used to detect IgM and IgG antibodies against the SARS-CoV-2 nucleocapsid antigen according to the manufacturer's instruction using a fully automated Cobas ${ }^{\circledR}$ e601 immunoassay analyser (Roche Diagnostics). ${ }^{25}$

\section{Sample size calculation}

The formula used to determine the sample size in each stratum was given by

$$
n=\frac{N}{N-1} \times P \times Q \times \frac{1}{C V^{2} \times P^{2}+\frac{P \times Q}{N-1}}
$$

$\mathrm{N}$ being the population size in each stratum; $\mathrm{P}$ the expected prevalence in the stratum; $\mathrm{Q}=1-\mathrm{P}$; and CV the coefficient of variation of the prevalence estimates within the stratum. In each stratum, the expected prevalence of infection was $20 \%$, and the coefficient of variation was $10 \%$. For the final calculation, a design effect of 2 was added. Thus, the minimum number of individuals per stratum was 800, totalling 3200 individuals to compose the sample. Predicting losses, the sample size was increased by $25 \%$ resulting in 4000 observations. 
medRxiv preprint doi: https://doi.org/10.1101/2020.08.28.20180463; this version posted September 1, 2020. The copyright holder for this

\section{Statistical analysis}

The basic sample weight of each selected unit (census sector, household, and individual) was calculated separately for each stratum, considering the inverse of the selection probability according to the sampling plan specified for the study.

The probability of selection of the census sector " $\mathrm{j}$ " in each stratum " $\mathrm{i}$ " of the sample is given by $30 / S_{i}$, where " $S_{i}$ " is the number of census sectors of the stratum " $i$ " in the population and the probability of the domicile of the census sector " $\mathrm{j}$ " of the stratum "i" being selected was obtained from the following expression: $34 / \mathrm{D}_{\mathrm{ij}}$, where " $\mathrm{D}_{\mathrm{ij}}$ " is the number of domiciles in sector " $\mathrm{j}$ " of the stratum " $\mathrm{i}$ " in the population. The probability of each resident in the selected household was given by $1 /$ (number of residents in the household). The number of sectors and domiciles was obtained from the 2010 Census of the IBGE.

Since losses, refusals, and non-responses occurred, the response rate in each stratum was also calculated. Considering that there were three stages, the final weight was obtained by the product of the basic weight in each stage and the response rate.

All analyses were performed using $\mathrm{R}$ version 4.0.2. Weighting factors, clustering, and stratification were incorporated into the analyses via the $\mathrm{R}$ survey package. Prevalence and $95 \%$ confidence interval $(95 \% \mathrm{CI})$ of SARS-CoV-2 infection was obtained according to the sociodemographic characteristics, adherence to NPI, self-reported symptoms, and the use of health services. The chi-square test, considering the study design, was used to compare the prevalence between groups. The McNemar test was used to compare adherence to NPI over time.

The IFR was estimated by dividing the estimated number of deaths by the estimated proportion of infections obtained by the serological survey multiplied by the stratified age and sex population estimates. ${ }^{4}$ The number of deaths reported on 8 August 2020 was abstracted from official sources. ${ }^{5}$ The IFR was estimated by the sex, the sex and age group, and the overall IFR was evaluated for the State of Maranhão and the first stratum (São Luís Island). The number of deaths occurring daily was estimated using Nowcasting by Bayesian Smoothing (NobBS), to consider reporting delays and underreporting of deaths attributable to COVID-19 (assuming a prior of 15\% for the State of Maranhão and $10 \%$ for the São Luís Island). This procedure incorporates uncertainty both in the delay distribution and in the evolution of the pandemic curve over time, resulting in smooth, time-correlated estimates of the number of deaths. ${ }^{26}$ Simulations were carried out using the NobBS R package, with a negative binomial model with an adaptation phase of 10000 
medRxiv preprint doi: https://doi.org/10.1101/2020.08.28.20180463; this version posted September 1, 2020. The copyright holder for this preprint (which was not certified by peer review) is the author/funder, who has granted medRxiv a license to display the preprint in

It is made available under a CC-BY-NC-ND 4.0 International license .

iterations and a burn-in of 10000 iterations for estimating deaths in the State of Maranhão, and the same parameters with 5000 iterations for the São Luís Island. The case reporting rate was obtained by dividing the number of reported cases by the number of estimated infections, multiplied by 100 .

\section{Ethical approval}

Ethical approval was obtained from the Research Ethics Committee of the Carlos Macieira Hospital of the Maranhão State Health Secretariat under CAAE number 34708620.2.0000.8907. Written informed consent was provided by the participants or the parents/legal guardians.

\section{Role of the funding source}

The funder facilitated data acquisition and helped in the analysis, interpretation, and writing.

The corresponding author confirms that he had full access to all the data in the study and had the final responsibility for the decision to submit for publication.

\section{Results}

A total of 3289 individuals (80.6\%) agreed to participate in the study. After the exclusion of samples with insufficient material or haemolysed samples, and cases in which it was not possible to link the result of the examination with the person, 3156 participants had their blood samples analysed (77.4\%). Comparing the sampling with the population distribution (age and sex estimates for 2020), males and people of working age were underrepresented in the sample.

Seroprevalence of total antibodies against SARS-CoV-2 was 40.4\% (95\%CI 35-6-45.3) in the State of Maranhão, Brazil. Seroprevalence varied by region, from $20 \cdot 0 \%$ in small municipalities with $<20,000$ inhabitants, reaching $47.6 \%$ in medium-sized municipalities from 20,000 to 100,000 inhabitants $(\mathrm{P}=0$-006). Seroprevalence in the São Luís Island, including the capital of the state, was $38.9 \%$. There were no significant differences in the prevalence according to the sex or age group (Table 1).

Whites had a lower point prevalence $(20.0 \%)$ compared with both the browns $(41.3 \%)$ and blacks (49.2\%) but of borderline significance (between 0.05 and 0.10). Persons with tertiary education had a lower prevalence of infection $(27 \cdot 5 \%)$ than their counterparts 
medRxiv preprint doi: https://doi.org/10.1101/2020.08.28.20180463; this version posted September 1, 2020. The copyright holder for this preprint (which was not certified by peer review) is the author/funder, who has granted medRxiv a license to display the preprint in

It is made available under a CC-BY-NC-ND 4.0 International license .

$(\mathrm{P}=0 \cdot 011)$. Although point prevalence was lower among those with a monthly family income above 3000 Brazilian Reals, the difference did not reach a significant level. Infection rates were higher among households with three dwellers $(44.9 \%)(\mathrm{P}=0.028)$ (Table 2).

Population adherence to NPI to contain the COVID-19 pandemic were mostly higher at the beginning of the pandemic than in the last month. Social distancing dropped from $52.7 \%$ to $37.4 \%(\mathrm{P}<0 \cdot 001)$. The percentage of wearing a face mask dropped from $61.4 \%$ to $55.5 \%(\mathrm{P}<0 \cdot 001)$. Differences in the infection rates between those who maintained social distancing and those who did not were evident both at the beginning of the pandemic (36.4\% vs $45.0 \%, \mathrm{P}=0.020)$ and in the last month (34.0\% vs $44.3 \%, \mathrm{P}=0.015)$. SARS-CoV-2 infection rates were significantly lower in the last month among mask wearers and those who maintained a distance of at least $1.5 \mathrm{~m}$ from other people compared to their counterparts $(\mathrm{P}=0.036$ for mask-wearing and $\mathrm{P}=0.030$ for physical distancing) (Table 3).

Differences in the self-reporting symptoms were highly significant comparing those with and without antibodies to SARS-CoV-2. Among the infected, $62 \cdot 2 \%$ had more than three symptoms, whereas $26.0 \%$ were asymptomatic and, $11.8 \%$ reported only one or two symptoms (oligosymptomatic). The predominant symptoms among those who tested positive for SARS-CoV-2 were anosmia/hyposmia (49.5\%), ageusia/dysgeusia (47.7\%), fever $(45 \cdot 6 \%)$, headache $(45 \cdot 4 \%)$, myalgia (43.6\%), and fatigue (41.1\%) (Table 4$)$.

Among the infected, $27.6 \%$ sought medical care and most received it. A small minority (1.9\%) was hospitalized for over 24 hours, $13.3 \%$ were told they were suspected of having COVID-19, 4.3\% performed an RT-PCR for SARS-CoV-2, and $13 \cdot 5 \%$ performed a point of care test/serology for SARS-CoV-2 (Table 5).

The IFR was $0 \cdot 15 \%$ for the State of Maranhão, and $0 \cdot 30 \%$ for the São Luís Island taking reporting delays by NobBS into account. The estimates increased a little to $0 \cdot 17 \%$ and $0 \cdot 34 \%$, respectively, after allowing underreporting of COVID-19 deaths. IFR was higher for males and advanced age groups (Table 6). The case reporting rate was $4.5 \%$ for the State of Maranhão, and 3.4\% for the São Luís Island, resulting in a ratio of the estimated infection to the reported cases as 22.2 for the State of Maranhão, and 29.9 for the São Luís Island (Table 7).

Figures 1 and 2 show dates of introduction of compulsory NPI, the weekly number of deaths by dates of occurrence and reporting, and estimates of the weekly number of deaths based on NobBS taking reporting delays, and reporting delays plus underreporting into 
medRxiv preprint doi: https://doi.org/10.1101/2020.08.28.20180463; this version posted September 1, 2020. The copyright holder for this preprint (which was not certified by peer review) is the author/funder, who has granted medRxiv a license to display the preprint in

It is made available under a CC-BY-NC-ND 4.0 International license .

account. The pandemic peaked from 17 May 2020 to 23 May 2020 in the State of Maranhão and from 3 May 2020 to 9 May 2020 in the São Luís Island. Since then, the number of deaths has been decreasing, and economic activity has been gradually increasing while most restrictions, apart from banning mass gatherings and opening of public schools and universities, have been eased. Nearly three months since the beginning of the relaxation of social distancing, and despite increasing community mobility, reported deaths analysed by date of occurrence remain low.

\section{Discussion}

Population-based seroprevalence of SARS-CoV-2 in the State of Maranhão, Brazil was 40.4\%. To the best of our knowledge, this is the first population-based study to report a prevalence rate in this range, for an area as big as Italy. Results suggest that Maranhão is more than halfway through the herd immunity threshold, whatever its value. Although there is still doubt about what this threshold is, our data suggest that it is at least $\geq 40 \%$ and it does not seem to be as low as $20 \%$ as it has been suggested by some. ${ }^{6}$ However, herd immunity may not be uniform across populations, because it depends on whether the mixing of individuals across populations is homogeneous or heterogeneous and on the immunity duration. ${ }^{6}$

It seems that over $90 \%$ of all infected people develop detectable antibodies against SARSCoV-2 two weeks after infection. ${ }^{27}$ In addition, SARS-CoV-2 leads to robust memory $\mathrm{T}$ cell responses, suggesting that infection may at least prevent subsequent severe disease. ${ }^{28}$ Furthermore, cross-reactivity between SARS-CoV-2 and coronaviruses that cause the common cold may elicit additional protection against infection. ${ }^{29}$ Due to all these factors and based on a high seroprevalence of $40.4 \%$ achieved in the survey, our data suggests that herd immunity may be achieved sooner than expected.

Nevertheless, the achievement of herd immunity will not be sustained if protection wanes over time. ${ }^{30}$ Thus, durable immunity may not be attained before vaccination, and consequently, the population would remain susceptible to future recurrent outbreaks. ${ }^{6}$

In this study, we used the Elecsys ${ }^{\circledR}$ Anti-SARS-CoV-2 electrochemiluminescence immunoassay, which presented a high specificity rate of 99.7\% (95\%CI 99-2-100.0) and a positive predictive value (PPV) of $97.4 \%$ with a $10 \%$ seroprevalence rate. ${ }^{31}$ We have likely achieved a higher PPV because the prevalence in our survey was four times that seroprevalence rate. It has been shown that electrochemiluminescence immunoassays present higher sensitivity than lateral flow immunoassays. ${ }^{22}$ Most existing lateral flow 
medRxiv preprint doi: https://doi.org/10.1101/2020.08.28.20180463; this version posted September 1, 2020. The copyright holder for this

immunoassays do not attain an ideal performance to be used in seroprevalence surveys, especially if they are used with finger-prick. ${ }^{21}$ Therefore, as the test we used is more sensitive and specific, we were able to detect a higher percentage of persons with antibodies against SARS-CoV-2 with few false-positive results. The distribution and percentage of self-reported symptoms among the infected in our survey were similar to what has been reported by others, ${ }^{9,11,32}$ providing further evidence that a high falsepositive rate in our study is unlikely.

Most surveys did not report the difference in the infection rates by sex. ${ }^{9,11,13}$ Some surveys have shown that adolescents ${ }^{10}$ and those aged between 20-59 years tend to have higher infection rates. ${ }^{9,10}$ We did not find evidence proving that infection rates differ by sex, age group, skin colour, or income, but our sample size given the survey's complex sampling design lacked the statistical power to answer these questions. The infection rates were lower among those with tertiary education, in agreement with the São Paulo study. ${ }^{33}$

Infection rates were lower among mask wearers and among those who maintained social and physical distancing, suggesting that the use of face masks ${ }^{34}$ and social ${ }^{35,36}$ and physical distancing ${ }^{34}$ were necessary to avert further infections and deaths. However, adherence to NPI to curb the COVID-19 pandemic tended to diminish over time.

Infected persons were mostly symptomatic (62.2\%), and anosmia/hyposmia and ageusia/dysgeusia were the two most reported symptoms. Most cases were mild. These findings are in agreement with recent studies. ${ }^{18,32}$

Our estimate of the IFR for the State of Maranhão was lower than the rate $(0.71 \%)$ estimated for Brazil, ${ }^{9}$ the $0.90 \%$ estimate described for the UK and the combined estimate of $0.68 \%$ from a meta-analysis by Meyerowitz-Katz et al. (2020), ${ }^{17}$ but more in line with the $0 \cdot 24 \%$ combined estimate obtained by Ioannidis $(2020)^{10}$ and with the range of 0.30\%-0.50\% estimated by Bayesian Network Analysis. ${ }^{15}$ It has been shown that variations in IFR may be due to differences in the testing capacity, age structures, selective testing of high-risk populations, patterns of how deaths are attributed to COVID$19,{ }^{6}$ and strain on the health services. ${ }^{37}$ Therefore, IFR is likely to vary across populations. However, the IFR in Maranhão is one of the lowest reported to date, ${ }^{10}$ even after taking reporting delays and underreporting of COVID-19 deaths into account. The BCG vaccination that is widely used in Brazil may be one of the reasons to explain the lower IFR. ${ }^{38}$ Another possibility is that the circulating strain in Maranhão is more transmissible and less virulent. ${ }^{39}$ The more rapid and extensive spread of SARS-CoV-2 in the São Luís 
medRxiv preprint doi: https://doi.org/10.1101/2020.08.28.20180463; this version posted September 1, 2020. The copyright holder for this preprint (which was not certified by peer review) is the author/funder, who has granted medRxiv a license to display the preprint in

It is made available under a CC-BY-NC-ND 4.0 International license .

Island may be one of the reasons to explain its higher IFR than the entire State of Maranhão.

In our study, the case reporting rate was $4.5 \%$ for the State of Maranhão and $3.4 \%$ for the São Luís Island, resulting in a ratio of the estimated infection to the reported cases as $22 \cdot 2$ for the State of Maranhão and 29.9 for the São Luís Island. These ratios were higher than the value of $10 \cdot 3$ reported for Brazil. ${ }^{9}$

Our study has strong points: it is population-based, had a high response rate of $77.4 \%$, and we used a serum testing electrochemiluminescence immunoassay instead of a lateral flow immunoassay with finger-prick. There are some limitations: for some estimates, the confidence intervals were wide, and thus our power to detect statistically significant associations was lower than desired; some population groups (males and people of working age) were underrepresented in our sample.

\section{Contributors}

Antônio A M Silva, Lídio G Lima-Neto, Conceição M P S Azevedo, Léa M Costa, Maylla L B M Bragança, Allan K D B Filho, Bernardo B Wittlin, Bruno L C A Oliveira, Carolina A Carvalho, Erika B A F Thomaz, Eudes A Simões-Neto, Jamesson F Leite-Júnior, Marcos A G Campos, Rejane C S Queiroz, Vitória A Carvalho, Vanda M F Simões, Maria T S B Alves and Alcione M Santos contributed to the conception and design of the work, the acquisition, analysis, and interpretation of the data, and the draft of the manuscript. Bruno F Souza, Sérgio S Costa and Lécia M S Cosme contributed to the acquisition and analysis of the data. All authors have approved the submitted version.

\section{Declaration of interests}

We declare no competing interests.

\section{Acknowledgments}

The study was funded by the State Health Department of Maranhão, Brazil. 
medRxiv preprint doi: https://doi.org/10.1101/2020.08.28.20180463; this version posted September 1, 2020. The copyright holder for this preprint (which was not certified by peer review) is the author/funder, who has granted medRxiv a license to display the preprint in

It is made available under a CC-BY-NC-ND 4.0 International license .

\section{Research in context}

\section{Evidence before this study}

Of all the countries, Brazil is one of the most severely affected by coronavirus disease 2019 (COVID-19) pandemic. The government response has been controversial, and social distancing in the country has not reached levels sufficient to curb and contain the pandemic so far. Therefore, Brazil has become one of the global hotspots of the COVID19 pandemic. Maranhão is one of the states in Brazil where the pandemic gathered speed early. Population-based surveys are necessary to monitor infection progression since most cases are undetected. However, few population-based studies on the prevalence of severe acute respiratory syndrome coronavirus 2 (SARS-CoV-2) have been performed to date, especially in low-income and middle-income countries, and most of them have used lateral flow immunoassays with finger-prick, which may yield false-negative results, and thus underestimate the true infection rate. Therefore, population-based surveys using more sensitive diagnostic tests are warranted. In this population-based study, we estimated the overall seroprevalence of SARS-CoV-2 in the State of Maranhão, Brazil using a serum testing electrochemiluminescence immunoassay.

\section{Added value of this study}

We documented that seroprevalence of total antibodies against SARS-CoV-2 was 40.4\% (95\% CI 35-6-45.3). We reported that the population adherence to non-pharmaceutical interventions was higher at the beginning of the pandemic than in the last month and that SARS-CoV-2 infection rates were significantly lower among mask wearers and among those who maintained social and physical distancing in the last month compared to their counterparts. We also showed that among the infected, $26.0 \%$ were asymptomatic and $11.1 \%$ had one or two symptoms and that the predominant symptoms among those who tested positive for SARS-CoV-2 were anosmia/hyposmia (49.5\%), ageusia/dysgeusia $(47 \cdot 7 \%)$, fever $(45 \cdot 6 \%)$, headache $(45 \cdot 4 \%)$, myalgia $(43.6 \%)$, and fatigue $(41 \cdot 1 \%)$. The infection fatality rate was $0.17 \%$, higher for males and advanced age groups. Only $4.5 \%$ of all infections have been reported. The ratio of the estimated infections to the reported cases was $22 \cdot 2$.

\section{Implications of all the available evidence}

The reported population-based seroprevalence of $40 \cdot 4 \%$, was the highest and the closest to the herd immunity threshold reported to date, for an area as big as Italy. Whatever that 
medRxiv preprint doi: https://doi.org/10.1101/2020.08.28.20180463; this version posted September 1, 2020. The copyright holder for this preprint (which was not certified by peer review) is the author/funder, who has granted medRxiv a license to display the preprint in It is made available under a CC-BY-NC-ND 4.0 International license.

threshold, the State of Maranhão in Brazil is more than halfway through the herd immunity. Our results suggest that the herd immunity threshold is not as low as $20 \%$ but at least higher than or equal to around $40 \%$. There are suggestions that a sizeable part of the population may not be susceptible to the SARS-CoV-2 infection due to robust memory $\mathrm{T}$ cell responses and/or cross-reactivity between SARS-CoV-2 and other coronaviruses that cause the common cold or due to heterogeneity in susceptibility or exposure to infection. If these suggestions are true, with a high prevalence of $40 \cdot 4 \%$, we may achieve herd immunity sooner than expected. The infection fatality rate was $0 \cdot 17 \%$, one of the lowest reported so far, even after accounting for reporting delay and underreporting of COVID-19 deaths using Bayesian nowcasting. 
medRxiv preprint doi: https://doi.org/10.1101/2020.08.28.20180463; this version posted September 1, 2020. The copyright holder for this preprint (which was not certified by peer review) is the author/funder, who has granted medRxiv a license to display the preprint in

It is made available under a CC-BY-NC-ND 4.0 International license .

\section{References}

1 Johns Hopkins University. Johns Hopkins University. Coronavirus COVID-19 Global Cases by Johns Hopkins CSSE.

https://gisanddata.maps.arcgis.com/apps/opsdashboard/index.html\#/bda7594740f d40299423467b48e9ecf6 (accessed August 21, 2020).

2 The Lancet. COVID-19 in Brazil: “So what?” Lancet 2020; 395: 1461.

3 Candido DS, Claro IM, de Jesus JG, et al. Evolution and epidemic spread of SARS-CoV-2 in Brazil. Science 2020; published online July 23.

https://doi.org/10.1126/science.abd2161.

4 IBGE. Projeção da população por sexo e idades simples, em $1^{\circ}$ de julho 2010/2060.

ftp://ftp.ibge.gov.br/Projecao_da_Populacao/Projecao_da_Populacao_2018/proje coes_2018_populacao_idade_simples_2010_2060.xls (accessed August 18, 2020).

5 Maranhão. Secretaria de Estado da Saúde. Boletim Epidemiológico COVID-19. https://www.saude.ma.gov.br/wp-content/uploads/2020/08/BOLETIM-20-08.pdf (accessed August 21, 2020).

6 Randolph HE, Barreiro LB. Herd Immunity: Understanding COVID-19. Immunity 2020; 52: 737-41.

7 Aguas R, Corder RM, King JG, Gonçalves G, Ferreira MU, Gabriela Gomes MM. Herd immunity thresholds for SARS-CoV-2 estimated from unfolding epidemics. medRxiv 2020; published online July 24.

https://doi.org/10.1101/2020.07.23.20160762 (preprint).

8 Britton T, Ball F, Trapman P. A mathematical model reveals the influence of population heterogeneity on herd immunity to SARS-CoV-2. Science 2020; 369: 846-9.

9 Hallal PC, Hartwig FP, Lessa Horta B, et al. Remarkable Variability in SARSCoV-2 Antibodies across Brazilian Regions: Report on Two Successive Nationwide Serological Household Surveys. medRxiv 2020; published online May 30. https://doi.org/10.1101/2020.05.30.20117531 (preprint).

10 Ioannidis J. The infection fatality rate of COVID-19 inferred from seroprevalence data. medRxiv 2020; published online July 14.

https://doi.org/10.1101/2020.05.13.20101253 (preprint).

11 Pollán M, Pérez-Gómez B, Pastor-Barriuso R, et al. Prevalence of SARS-CoV-2 in Spain (ENE-COVID): a nationwide, population-based seroepidemiological study. Lancet 2020; 396: 535-44.

12 Rosenberg ES, Tesoriero JM, Rosenthal EM, et al. Cumulative incidence and diagnosis of SARS-CoV-2 infection in New York. Ann Epidemiol 2020; 48: 2329.e4.

13 Tess B, Alves MCGP, Reinach F, et al. Inquérito domiciliar para monitorar a soroprevalência da infecção pelo vírus SARS-CoV-2 em adultos no município de 
medRxiv preprint doi: https://doi.org/10.1101/2020.08.28.20180463; this version posted September 1, 2020. The copyright holder for this preprint (which was not certified by peer review) is the author/funder, who has granted medRxiv a license to display the preprint in

It is made available under a CC-BY-NC-ND 4.0 International license .

São Paulo. https://0dea032c-2432-4690-b1e5-

636d3cbeb2bf.filesusr.com/ugd/6b3408_90141a5c289e43cfb75c2ce6408d299e.p df (accessed August 21, 2020).

14 Russell TW, Hellewell J, Jarvis CI, et al. Estimating the infection and case fatality ratio for coronavirus disease (COVID-19) using age-adjusted data from the outbreak on the Diamond Princess cruise ship, February 2020.

Eurosurveillance 2020; 25: 2000256.

15 Verity R, Okell LC, Dorigatti I, et al. Estimates of the severity of coronavirus disease 2019 : a model-based analysis. Lancet Infect Dis 2020; 3099: 1-9.

16 Ing AJ, Cocks C, Green JP. COVID-19: in the footsteps of Ernest Shackleton. Thorax 2020; 75: 693-4.

17 Meyerowitz-Katz G, Merone L. A systematic review and meta-analysis of published research data on COVID-19 infection-fatality rates. medRxiv 2020; published online July 7. https://doi.org/10.1101/2020.05.03.20089854 (preprint).

18 Menezes AMB, Victora CG, Hartwig FP, et al. High prevalence of symptoms among Brazilian subjects with antibodies against 2 SARS-CoV-2: a nationwide household survey. medRxiv 2020; published online August 12. https://doi.org/10.1101/2020.08.10.20171942 (preprint).

19 Byambasuren O, Cardona M, Bell K, Clark J, McLaws M-L, Glasziou P. Estimating the Extent of True Asymptomatic COVID-19 and Its Potential for Community Transmission: Systematic Review and Meta-Analysis. medRxiv 2020; published online June 4. https://doi.org/10.1101/2020.05.10.20097543 (preprint).

20 Li R, Pei S, Chen B, et al. Substantial undocumented infection facilitates the rapid dissemination of novel coronavirus (SARS-CoV-2). Science 2020; 368: 489-93.

21 Flower B, Brown JC, Simmons B, et al. Clinical and laboratory evaluation of SARS-CoV-2 lateral flow assays for use in a national COVID-19 seroprevalence survey. Thorax 2020; published online August 12.

https://doi.org/10.1136/thoraxjnl-2020-215732.

22 Lisboa Bastos M, Tavaziva G, Abidi SK, et al. Diagnostic accuracy of serological tests for covid-19: systematic review and meta-analysis. BMJ 2020; 370: $\mathrm{m} 2516$.

23 UNESCO. The International Standard Classification of Education ISCED 2011. Montreal, QC: UNESCO Institute for Statistics, 2012.

24 Travassos C, Williams DR. The concept and measurement of race and their relationship to public health: a review focused on Brazil and the United States. Cad Saude Publica 2004; 20: 660-78.

25 Muench P, Jochum S, Wenderoth V, et al. Development and Validation of the Elecsys Anti-SARS-CoV-2 Immunoassay as a Highly Specific Tool for Determining Past Exposure to SARS-CoV-2. J Clin Microbiol 2020; published online August 3. https://doi.org/10.1128/JCM.01694-20. 
medRxiv preprint doi: https://doi.org/10.1101/2020.08.28.20180463; this version posted September 1, 2020. The copyright holder for this preprint (which was not certified by peer review) is the author/funder, who has granted medRxiv a license to display the preprint in

It is made available under a CC-BY-NC-ND 4.0 International license .

26 McGough SF, Johansson MA, Lipsitch M, Menzies NA. Nowcasting by Bayesian Smoothing: A flexible, generalizable model for real-time epidemic tracking. PLOS Comput Biol 2020; 16: e1007735.

27 Health Information and Quality Authority. Evidence summary of the immune response following infection with SARS- CoV-2 or other human coronaviruses. https://www.hiqa.ie/sites/default/files/2020-06/Evidence-summary_SARS-CoV2-immune-response.pdf (accessed August 21, 2020).

28 Sekine T, Perez-Potti A, Rivera-Ballesteros $\mathrm{O}$, et al. Robust $\mathrm{T}$ cell immunity in convalescent individuals with asymptomatic or mild COVID-19. Cell 2020; published online August 11. https://doi.org/10.1016/j.cell.2020.08.017.

29 Grifoni A, Weiskopf D, Ramirez SI, et al. Targets of T Cell Responses to SARSCoV-2 Coronavirus in Humans with COVID-19 Disease and Unexposed Individuals. Cell 2020; 181: 1489-1501.e15.

30 Long Q-X, Tang X-J, Shi Q-L, et al. Clinical and immunological assessment of asymptomatic SARS-CoV-2 infections. Nat Med 2020; 26: 1200-4.

31 Perkmann T, Perkmann-Nagele N, Breyer M-K, et al. Side by side comparison of three fully automated SARS-CoV-2 antibody assays with a focus on specificity. Clin Chem 2020; published online August 10. https://doi.org/10.1093/clinchem/hvaa198.

32 Ward H, Atchison C, Whitaker M, et al. Antibody prevalence for SARS-CoV-2 following the peak of the pandemic in England: REACT2 study in 100,000 adults. medRxiv 2020; published online August 14. https://doi.org/10.1101/2020.08.12.20173690 (preprint).

33 Tess B, Granato C, Alves MCGP, et al. SARS-CoV-2 seroprevalence in the municipality of São Paulo, Brazil, ten weeks after the first reported case. medRxiv 2020; published online June 29. https://doi.org/10.1101/2020.06.29.20142331 (preprint).

34 Chu DK, Akl EA, Duda S, et al. Physical distancing, face masks, and eye protection to prevent person-to-person transmission of SARS-CoV-2 and COVID-19: a systematic review and meta-analysis. Lancet 2020; 395: 1973-87.

35 Flaxman S, Mishra S, Gandy A, et al. Estimating the effects of nonpharmaceutical interventions on COVID-19 in Europe. Nature 2020; 584: 257 61 .

36 Walker PGT, Whittaker C, Watson OJ, et al. The impact of COVID-19 and strategies for mitigation and suppression in low- and middle-income countries. Science 2020; 369: 413-22.

37 Kenyon C. COVID-19 Infection Fatality Rate Associated with Incidence-A Population-Level Analysis of 19 Spanish Autonomous Communities. Biology 2020; 9: 128.

38 Escobar LE, Molina-Cruz A, Barillas-Mury C. BCG vaccine protection from severe coronavirus disease 2019 (COVID-19). Proc Natl Acad Sci 2020; 117: 17720-6. 
medRxiv preprint doi: https://doi.org/10.1101/2020.08.28.20180463; this version posted September 1 , 2020. The copyright holder for this preprint (which was not certified by peer review) is the author/funder, who has granted medRxiv a license to display the preprint in

It is made available under a CC-BY-NC-ND 4.0 International license .

39 Korber B, Fischer WM, Gnanakaran S, et al. Tracking Changes in SARS-CoV-2 Spike: Evidence that D614G Increases Infectivity of the COVID-19 Virus. Cell 2020; 182: 812-827.e19. 
medRxiv preprint doi: https://doi.org/10.1101/2020.08.28.20180463; this version posted September 1, 2020. The copyright holder for this preprint (which was not certified by peer review) is the author/funder, who has granted medRxiv a license to display the preprint in

It is made available under a CC-BY-NC-ND 4.0 International license .

Table 1. Prevalence of antibodies against SARS-CoV-2 by region, sex, and age group, State of Maranhão, Brazil, 2020

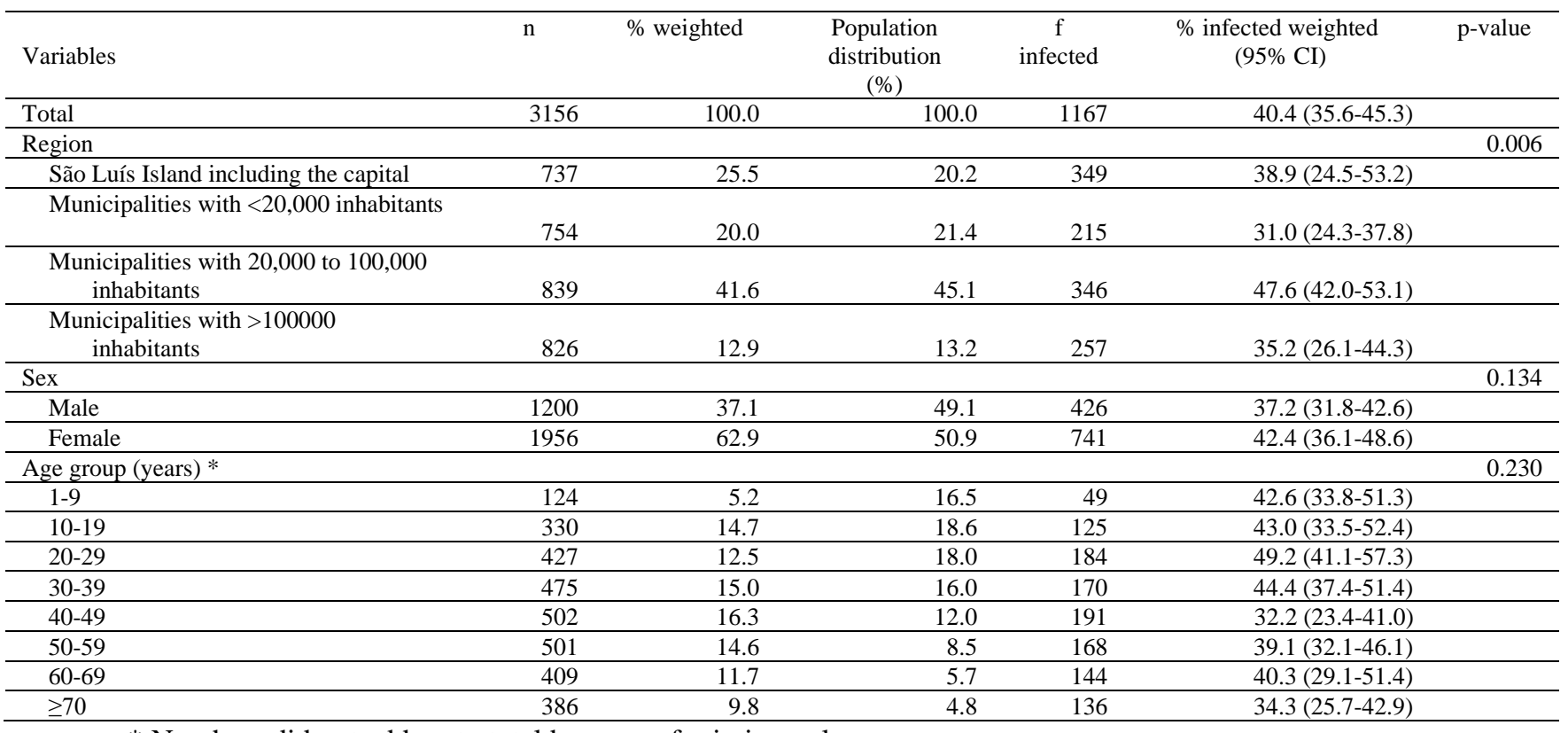

* Numbers did not add up to total because of missing values

95\% CI: 95\% confidence interval; SARS-CoV-2: severe acute respiratory syndrome coronavirus 2 
medRxiv preprint doi: https://doi.org/10.1101/2020.08.28.20180463; this version posted September 1, 2020. The copyright holder for this preprint (which was not certified by peer review) is the author/funder, who has granted medRxiv a license to display the preprint in

It is made available under a CC-BY-NC-ND 4.0 International license .

Table 2. Prevalence of antibodies against SARS-CoV-2 by race, schooling, family income, and number of residents, State of Maranhão, Brazil, 2020

\begin{tabular}{|c|c|c|c|c|c|}
\hline Variables & $\mathrm{n}$ & $\%$ weighted & f infected & $\begin{array}{c}\% \text { infected weighted } \\
(95 \% \mathrm{CI})\end{array}$ & p-value \\
\hline Skin colour/race* & & & & & $0 \cdot 080$ \\
\hline White & 590 & $20 \cdot 0$ & 200 & $32 \cdot 2(20 \cdot 1-44 \cdot 4)$ & \\
\hline Brown & 2100 & $67 \cdot 4$ & 767 & $41 \cdot 3(37 \cdot 1-45 \cdot 4)$ & \\
\hline Black & 396 & $12 \cdot 6$ & 177 & $49 \cdot 1(42 \cdot 3-55 \cdot 9)$ & \\
\hline $\begin{array}{l}\text { Head of the household's schooling } \\
\text { (years)** }\end{array}$ & & & & & $0 \cdot 011$ \\
\hline Primary/Lower secondary & 1369 & $37 \cdot 7$ & 487 & $40 \cdot 9(35 \cdot 4-46 \cdot 4)$ & \\
\hline Upper secondary & 1251 & $41 \cdot 9$ & 512 & $46 \cdot 2(41 \cdot 3-51 \cdot 2)$ & \\
\hline Tertiary & 517 & $20 \cdot 4$ & 161 & $27 \cdot 5(16 \cdot 9-38 \cdot 1)$ & \\
\hline $\begin{array}{l}\text { Monthly family income (Brazilian Real) } \\
\text { *** }\end{array}$ & & & & & $0 \cdot 101$ \\
\hline$<1000$ & 607 & $17 \cdot 7$ & 222 & $40 \cdot 8(34 \cdot 6-46 \cdot 9)$ & \\
\hline $1000 \mathrm{a}<2000$ & 1405 & $42 \cdot 5$ & 540 & $45 \cdot 9(41 \cdot 0-50 \cdot 9)$ & \\
\hline $2000 \mathrm{a}<3000$ & 617 & $20 \cdot 8$ & 243 & $42 \cdot 9(35 \cdot 7-50 \cdot 2)$ & \\
\hline$>3000$ & 493 & $19 \cdot 0$ & 155 & $27 \cdot 9(17 \cdot 0-38 \cdot 9)$ & \\
\hline Number of residents & & & & & $0 \cdot 028$ \\
\hline 1 & 386 & 3.9 & 122 & $35 \cdot 4(27 \cdot 2-43 \cdot 6)$ & \\
\hline 2 & 840 & $15 \cdot 7$ & 302 & $37 \cdot 7(32 \cdot 0-43 \cdot 5)$ & \\
\hline 3 & 739 & $21 \cdot 2$ & 297 & $44 \cdot 9(40 \cdot 0-49 \cdot 8)$ & \\
\hline 4 & 628 & $28 \cdot 0$ & 234 & $38 \cdot 8(29 \cdot 0-48 \cdot 5)$ & \\
\hline$\geq 5$ & 563 & $31 \cdot 2$ & 212 & $40 \cdot 9(33 \cdot 5-48 \cdot 3)$ & \\
\hline
\end{tabular}

* yellow and indigenous were excluded because they were too few for a meaningful analysis ** Numbers did not add up to total because of missing values

*** 1 Brazilian Real ( $\mathrm{R} \$$ ) is equivalent to approximately US\$ 5.60 US dollars

95\% CI: 95\% confidence interval; SARS-CoV-2: severe acute respiratory syndrome coronavirus 2 
medRxiv preprint doi: https://doi.org/10.1101/2020.08.28.20180463; this version posted September 1, 2020. The copyright holder for this preprint (which was not certified by peer review) is the author/funder, who has granted medRxiv a license to display the preprint in

It is made available under a CC-BY-NC-ND 4.0 International license .

Table 3. Prevalence of antibodies against SARS-CoV-2 according to adherence to nonpharmaceutical interventions at the beginning of the pandemic and in the last month, State of Maranhão, Brazil, 2020

\begin{tabular}{|c|c|c|c|c|c|}
\hline Non-pharmaceutical interventions & $\mathrm{n}$ & $\%$ weighted & f infected & $\begin{array}{c}\% \text { infected weighted } \\
(95 \% \mathrm{CI})\end{array}$ & p-value \\
\hline \multicolumn{6}{|l|}{ At the beginning of the pandemic } \\
\hline Social distancing & & & & & $0 \cdot 020$ \\
\hline Yes* & 1764 & $52 \cdot 7$ & 610 & $36 \cdot 4(30 \cdot 6-42 \cdot 2)$ & \\
\hline Wearing of face masks & & & & & $0 \cdot 395$ \\
\hline No & 1153 & $38 \cdot 6$ & 423 & $42 \cdot 3(35 \cdot 8-48 \cdot 8)$ & \\
\hline Hand hygiene & & & & & $0 \cdot 285$ \\
\hline No & 1455 & $47 \cdot 9$ & 554 & $42 \cdot 7(36 \cdot 9-48 \cdot 4)$ & \\
\hline Yes*** & 1701 & $52 \cdot 1$ & 613 & $38 \cdot 4(31 \cdot 9-44 \cdot 9)$ & \\
\hline Physical distancing & & & & & $0 \cdot 065$ \\
\hline No & 1548 & $52 \cdot 2$ & 602 & $43 \cdot 5(37 \cdot 6-49 \cdot 4)$ & \\
\hline Yes**** & 1608 & $47 \cdot 8$ & 565 & $37 \cdot 1(31 \cdot 4-42 \cdot 8)$ & \\
\hline Yes* & 1281 & $37 \cdot 4$ & 410 & $34 \cdot 0(26 \cdot 5-41 \cdot 4)$ & \\
\hline Wearing of face masks & & & & & $0 \cdot 036$ \\
\hline No & 1310 & $44 \cdot 5$ & 517 & $45 \cdot 9(40 \cdot 6-51 \cdot 3)$ & \\
\hline Yes** & 1846 & $55 \cdot 5$ & 650 & $36 \cdot 0(29 \cdot 1-43 \cdot 0)$ & \\
\hline Hand hygiene & & & & & 0.095 \\
\hline No & 1557 & $51 \cdot 6$ & 612 & $44 \cdot 4(39 \cdot 1-49 \cdot 7)$ & \\
\hline Yes*** & 1599 & $48 \cdot 4$ & 555 & $36 \cdot 2(28 \cdot 7-43 \cdot 8)$ & \\
\hline Physical distancing & & & & & 0.030 \\
\hline No & 1817 & $61 \cdot 0$ & 710 & $43 \cdot 3(38 \cdot 0-48 \cdot 6)$ & \\
\hline Yes**** & 1339 & $39 \cdot 0$ & 457 & $35 \cdot 9(29 \cdot 7-42 \cdot 2)$ & \\
\hline
\end{tabular}

\footnotetext{
* never leaves home or seldom goes out, with a maximum of one outing every fifteen days

** uses mask on all exits and does not remove or seldom removes the mask from the face

*** sanitizes the hands $\geq 6$ times per turn (morning, afternoon, and night) with soap or an alcohol gel **** never or hardly ever comes within $1.5 \mathrm{~m}$ of other people

95\% CI: 95\% confidence interval; SARS-CoV-2: severe acute respiratory syndrome coronavirus 2
} 
medRxiv preprint doi: https://doi.org/10.1101/2020.08.28.20180463; this version posted September 1, 2020. The copyright holder for this preprint (which was not certified by peer review) is the author/funder, who has granted medRxiv a license to display the preprint in

It is made available under a CC-BY-NC-ND 4.0 International license .

Table 4. Reported symptoms of SARS-CoV-2 infection, State of Maranhão, Brazil, 2020

\begin{tabular}{|c|c|c|c|c|c|}
\hline \multirow[b]{2}{*}{ Variables } & \multicolumn{2}{|r|}{ Non-infected $(\mathrm{n}=1989)$} & \multicolumn{2}{|r|}{ Infected $(n=1167)$} & \multirow[b]{2}{*}{ p-value } \\
\hline & $\mathrm{n}$ & $\begin{array}{l}\% \text { weighted } \\
(95 \% \mathrm{CI})\end{array}$ & $\mathrm{n}$ & $\begin{array}{l}\% \text { weighted } \\
(95 \% \mathrm{CI})\end{array}$ & \\
\hline Self-reported symptom rating* & & & & & $<0 \cdot 001$ \\
\hline Asymptomatic & 1104 & $52 \cdot 1(47 \cdot 3-56 \cdot 9)$ & 320 & $26 \cdot 0(21 \cdot 0-31 \cdot 0)$ & \\
\hline Oligosymptomatic (1 to 2 symptoms) & 427 & $22 \cdot 8(18 \cdot 8-26 \cdot 7)$ & 134 & $11 \cdot 8(8 \cdot 9-14 \cdot 6)$ & \\
\hline Symptomatic ( $\geq 3$ symptoms) & 458 & $25 \cdot 2(21 \cdot 8-28 \cdot 5)$ & 713 & $62 \cdot 2(56 \cdot 2-68 \cdot 3)$ & \\
\hline \multicolumn{6}{|l|}{ Self-reported symptoms } \\
\hline Fever & 296 & $16 \cdot 7(13 \cdot 1-20 \cdot 4)$ & 494 & $45 \cdot 6(39 \cdot 9-51 \cdot 3)$ & $<0 \cdot 001$ \\
\hline Shivers & 253 & $13 \cdot 7(9 \cdot 9-17 \cdot 6)$ & 379 & $34 \cdot 3(29 \cdot 5-39 \cdot 2)$ & $<0 \cdot 001$ \\
\hline Sore throat & 345 & $18 \cdot 3(14 \cdot 7-22 \cdot 0)$ & 378 & $34 \cdot 5(30 \cdot 1-39 \cdot 0)$ & $<0 \cdot 001$ \\
\hline Cough & 356 & $17 \cdot 6(13 \cdot 7-21 \cdot 5)$ & 369 & $33 \cdot 1(29 \cdot 7-36 \cdot 5)$ & $<0 \cdot 001$ \\
\hline Dyspnoea & 184 & $10 \cdot 9(8 \cdot 4-13 \cdot 4)$ & 209 & $18 \cdot 6(15 \cdot 0-22 \cdot 2)$ & 0.001 \\
\hline Runny nose & 370 & $19 \cdot 2(16 \cdot 0-22 \cdot 3)$ & 364 & $32 \cdot 2(28 \cdot 0-36 \cdot 5)$ & $<0 \cdot 001$ \\
\hline Palpitations & 204 & $9 \cdot 5(7 \cdot 1-11 \cdot 9)$ & 178 & $15 \cdot 6(12 \cdot 1-19 \cdot 2)$ & $<0 \cdot 001$ \\
\hline Anosmia/Hyposmia & 117 & $7 \cdot 3(5 \cdot 0-9 \cdot 6)$ & 547 & $49 \cdot 5(42 \cdot 5-56 \cdot 5)$ & $<0 \cdot 001$ \\
\hline Ageusia/Dysgeusia & 133 & $8 \cdot 2(5 \cdot 8-10 \cdot 5)$ & 535 & $47 \cdot 7(40 \cdot 4-54 \cdot 9)$ & $<0 \cdot 001$ \\
\hline Diarrhoea & 186 & $8.9(6 \cdot 5-11 \cdot 2)$ & 210 & $18 \cdot 1(15 \cdot 1-21 \cdot 2)$ & $<0 \cdot 001$ \\
\hline Nausea/vomiting & 146 & $7 \cdot 2(5 \cdot 2-9 \cdot 2)$ & 177 & $15 \cdot 1(12 \cdot 0-18 \cdot 2)$ & $<0.001$ \\
\hline Headache & 509 & $27 \cdot 5(22 \cdot 7-32 \cdot 2)$ & 491 & $45 \cdot 4(38 \cdot 7-52 \cdot 0)$ & $<0 \cdot 001$ \\
\hline Abdominal pain & 201 & $10 \cdot 8(7 \cdot 7-13 \cdot 9)$ & 196 & $19 \cdot 8(14 \cdot 5-25 \cdot 1)$ & $0 \cdot 009$ \\
\hline Myalgia & 368 & $17 \cdot 9(14 \cdot 0-21 \cdot 8)$ & 485 & $43 \cdot 6(36 \cdot 8-50 \cdot 3)$ & $<0 \cdot 001$ \\
\hline Fatigue & 333 & $17 \cdot 1(13 \cdot 0-21 \cdot 3)$ & 449 & $41 \cdot 1(34 \cdot 5-47 \cdot 7)$ & $<0 \cdot 001$ \\
\hline Loss of appetite & 217 & $11 \cdot 1(8 \cdot 2-14 \cdot 0)$ & 396 & $35 \cdot 2(29 \cdot 2-41 \cdot 2)$ & $<0.001$ \\
\hline
\end{tabular}

* Asymptomatic: no symptoms; oligosymptomatic: presence of 1 to 2 symptoms without anosmia/hyposmia or ageusia/dysgeusia; symptomatic: anosmia/hyposmia or ageusia/dysgeusia or more than 2 symptoms including fever, chills, sore throat, cough, dyspnoea, diarrhoea, nausea/vomiting, headache, fatigue, and myalgia

95\% CI: 95\% confidence interval; SARS-CoV-2: severe acute respiratory syndrome coronavirus 2 
medRxiv preprint doi: https://doi.org/10.1101/2020.08.28.20180463; this version posted September $1,2020$. The copyright holder for this preprint (which was not certified by peer review) is the author/funder, who has granted medRxiv a license to display the preprint in

It is made available under a CC-BY-NC-ND 4.0 International license .

Table 5. Use of health services by individuals with SARS-CoV-2 antibodies, State of Maranhão, Brazil, 2020

\begin{tabular}{|c|c|c|}
\hline Variables & $\mathrm{n}$ & $\%(95 \% \mathrm{CI})$ \\
\hline \multicolumn{3}{|l|}{ Looked for health service } \\
\hline No & 888 & $72 \cdot 4(64 \cdot 6-80 \cdot 3)$ \\
\hline Yes & 279 & $27 \cdot 6(19 \cdot 7-35 \cdot 4)$ \\
\hline \multicolumn{3}{|l|}{ Received care when sought health service } \\
\hline Yes & 239 & $19 \cdot 0(14 \cdot 9-23 \cdot 0)$ \\
\hline No & 40 & $8 \cdot 6(0 \cdot 0-18 \cdot 1)$ \\
\hline Did not look for health service & 888 & $72 \cdot 4(64 \cdot 6-80 \cdot 3)$ \\
\hline \multicolumn{3}{|l|}{ Hospitalized for over 24 hours } \\
\hline No & 1148 & $98 \cdot 1(96 \cdot 9-99 \cdot 2)$ \\
\hline Yes & 19 & $1 \cdot 9(0 \cdot 8-3 \cdot 1)$ \\
\hline \multicolumn{3}{|c|}{ Received a medical diagnosis of suspected COVID-19 } \\
\hline No & 1014 & $86 \cdot 7(83 \cdot 1-90 \cdot 2)$ \\
\hline Yes & 153 & $13 \cdot 3(9 \cdot 8-16 \cdot 9)$ \\
\hline \multicolumn{3}{|l|}{ Performed RT-PCR for SARS-CoV-2 } \\
\hline No & 1123 & $95 \cdot 7(93 \cdot 5-98 \cdot 0)$ \\
\hline Yes & 44 & $4 \cdot 3(2 \cdot 0-6 \cdot 5)$ \\
\hline \multicolumn{3}{|c|}{ Performed antibody test (point-of-care/serology) for SARS-CoV-2 } \\
\hline No & 1019 & $86 \cdot 5(82 \cdot 8-90 \cdot 1)$ \\
\hline Yes & 148 & $13 \cdot 5(9 \cdot 9-17 \cdot 2)$ \\
\hline Total & 1167 & $100 \cdot 0$ \\
\hline
\end{tabular}

95\% CI: 95\% confidence interval; SARS-CoV-2: severe acute respiratory syndrome coronavirus 2 
medRxiv preprint doi: https://doi.org/10.1101/2020.08.28.20180463; this version posted September 1, 2020. The copyright holder for this preprint (which was not certified by peer review) is the author/funder, who has granted medRxiv a license to display the preprint in

It is made available under a CC-BY-NC-ND 4.0 International license .

Table 6. Estimated number of infections, deaths, and infection fatality rates of SARS-CoV-2 by sex and age groups, State of Maranhão and São Luís Island, Brazil, 2020.

\begin{tabular}{|c|c|c|c|c|c|c|}
\hline Sex & $\begin{array}{l}\text { Age } \\
\text { Group, } \\
\text { years }\end{array}$ & $\begin{array}{l}\text { Estimated } \\
\text { number of } \\
\text { infections }\end{array}$ & $\begin{array}{c}\text { Number of Deaths } \\
\text { (estimated by } \\
\text { nowcasting) }\end{array}$ & $\begin{array}{l}\text { IFR } \\
(\%)\end{array}$ & $\begin{array}{l}\text { Number of Deaths (estimated } \\
\text { by nowcasting and accounting } \\
\text { for } 15 \% \text { underreporting) }\end{array}$ & $\begin{array}{l}\text { IFR } \\
(\%)\end{array}$ \\
\hline \multicolumn{7}{|l|}{ Male } \\
\hline & $0-9$ & 274,241 & 9 & 0.00 & 11 & 0.00 \\
\hline & $10-19$ & 236,559 & 13 & 0.01 & 15 & $0 \cdot 01$ \\
\hline & $20-29$ & 303,111 & 22 & 0.01 & 26 & 0.01 \\
\hline & $30-39$ & 198,478 & 76 & 0.04 & 90 & 0.05 \\
\hline & $40-49$ & 100,908 & 163 & $0 \cdot 16$ & 192 & $0 \cdot 19$ \\
\hline & $50-59$ & 101,695 & 280 & 0.28 & 329 & $0 \cdot 32$ \\
\hline & $60-69$ & 64,637 & 623 & 0.96 & 733 & $1 \cdot 13$ \\
\hline & $\geq 70$ & 67,000 & 1437 & $2 \cdot 15$ & 1691 & $2 \cdot 52$ \\
\hline & Total & $1,299,992$ & 2624 & $0 \cdot 20$ & 3087 & $0 \cdot 24$ \\
\hline \multicolumn{7}{|l|}{ Female } \\
\hline & $0-9$ & 228,212 & 16 & 0.01 & 18 & 0.01 \\
\hline & $10-19$ & 323,171 & 5 & 0.00 & 6 & $0 \cdot 00$ \\
\hline & $20-29$ & 320,049 & 18 & 0.01 & 21 & $0 \cdot 01$ \\
\hline & 30-39 & 282,436 & 62 & 0.02 & 73 & $0 \cdot 03$ \\
\hline & $40-49$ & 155,868 & 83 & 0.05 & 98 & 0.06 \\
\hline & $50-59$ & 132,770 & 174 & $0 \cdot 13$ & 204 & $0 \cdot 15$ \\
\hline & $60-69$ & 94,033 & 359 & $0 \cdot 38$ & 422 & 0.45 \\
\hline & $\geq 70$ & 48,838 & 932 & 1.91 & 1097 & $2 \cdot 25$ \\
\hline & Total & $1,533,005$ & 1648 & $0 \cdot 11$ & 1939 & $0 \cdot 13$ \\
\hline \multicolumn{7}{|l|}{ Overall } \\
\hline & $0-9$ & 500,448 & 25 & $0 \cdot 00$ & 29 & $0 \cdot 01$ \\
\hline & $10-19$ & 567,266 & 18 & 0.00 & 21 & $0 \cdot 00$ \\
\hline & 20-29 & 628,088 & 40 & 0.01 & 47 & 0.01 \\
\hline & $30-39$ & 505,975 & 139 & 0.03 & 163 & $0 \cdot 03$ \\
\hline & $40-49$ & 275,270 & 246 & 0.09 & 289 & $0 \cdot 11$ \\
\hline & $50-59$ & 237,395 & 453 & $0 \cdot 19$ & 533 & $0 \cdot 22$ \\
\hline & $60-69$ & 162,429 & 982 & 0.60 & 1155 & 0.71 \\
\hline & $\geq 70$ & 116,065 & 2370 & $2 \cdot 04$ & 2788 & $2 \cdot 40$ \\
\hline & Total & $2,877,454$ & 4272 & $0 \cdot 15$ & 5026 & $0 \cdot 17$ \\
\hline \multicolumn{7}{|c|}{ São Luís Island } \\
\hline Overall & Total & 556,611 & 1695 & $0 \cdot 30$ & 1883 & $0 \cdot 34$ \\
\hline
\end{tabular}

SARS-CoV-2: severe acute respiratory syndrome coronavirus 2; IFR: infection fatality rate 
medRxiv preprint doi: https://doi.org/10.1101/2020.08.28.20180463; this version posted September 1 , 2020. The copyright holder for this preprint (which was not certified by peer review) is the author/funder, who has granted medRxiv a license to display the preprint in

It is made available under a CC-BY-NC-ND 4.0 International license .

Table 7. Estimated number of infections, number of official reported cases, case reporting rate, and ratio of the estimated infections to the reported cases of SARS-CoV-2, State of Maranhão and São Luís Island, Brazil, 2020.

\begin{tabular}{lcr}
\hline Estimates & Maranhão & São Luís Island \\
\hline Estimated number of infections $(95 \% \mathrm{CI})$ & $2,877,454$ & 556,611 \\
\hline Number of officially reported cases & 129,700 & $3 \cdot 646$ \\
\hline Case reporting rate \% (95\% CI) & $4 \cdot 5$ & $29 \cdot 9$ \\
\hline Ratio of the estimated infections to the reported cases $(95 \% \mathrm{CI})$ & $22 \cdot 2$ & \\
\hline
\end{tabular}

95\% CI: 95\% confidence interval; SARS-CoV-2: severe acute respiratory syndrome coronavirus 2 
medRxiv preprint doi: https://doi.org/10.1101/2020.08.28.20180463; this version posted September 1, 2020. The copyright holder for this preprint (which was not certified by peer review) is the author/funder, who has granted medRxiv a license to display the preprint in

It is made available under a CC-BY-NC-ND 4.0 International license .

Figure 1. Weekly number of deaths by occurrence and reporting date, and estimated by Bayesian nowcasting from 15 March to 15 August, State of Maranhão, Brazil, 2020

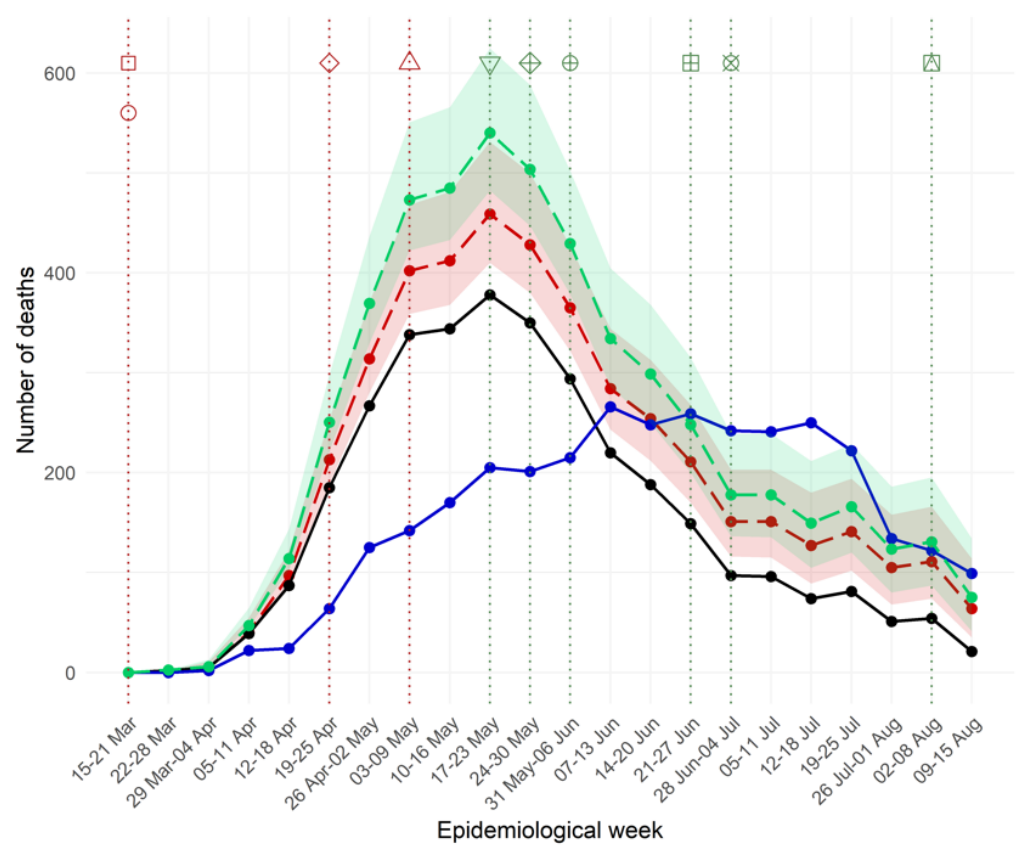

Interventions

School closure, mass gatherings, and events banned

$\square$ Closure of non-essential services

$\diamond$ Mandatory use of face mask

$\triangle$ Lockdown decreed at São Luis Island

$\nabla$ Lockdown end at São Luis Island

$\oplus$ Reopening of non-essential small businesses

$\oplus$ Reopening of non-essential commercial businesses

$\boxplus$ Reopening of gyms

\& Reopening of restaurants and bars

$\triangle \quad$ Reopening of private schools and universities

Legend

- Deaths by occurrence date estimated by

sian nowcasting

$\rightarrow$ Deaths by occurrence date

$\rightarrow$ Deaths by reporting date

- Deaths by occurrence date estimated by Bayesian nowcasting accouting for $15 \%$ underreporting 
medRxiv preprint doi: https://doi.org/10.1101/2020.08.28.20180463; this version posted September 1, 2020. The copyright holder for this preprint (which was not certified by peer review) is the author/funder, who has granted medRxiv a license to display the preprint in

It is made available under a CC-BY-NC-ND 4.0 International license .

Figure 2. Weekly number of deaths by occurrence and reporting date, and estimated by Bayesian nowcasting from 15 March to 15 August, São Luís Island, State of Maranhão, Brazil, 2020

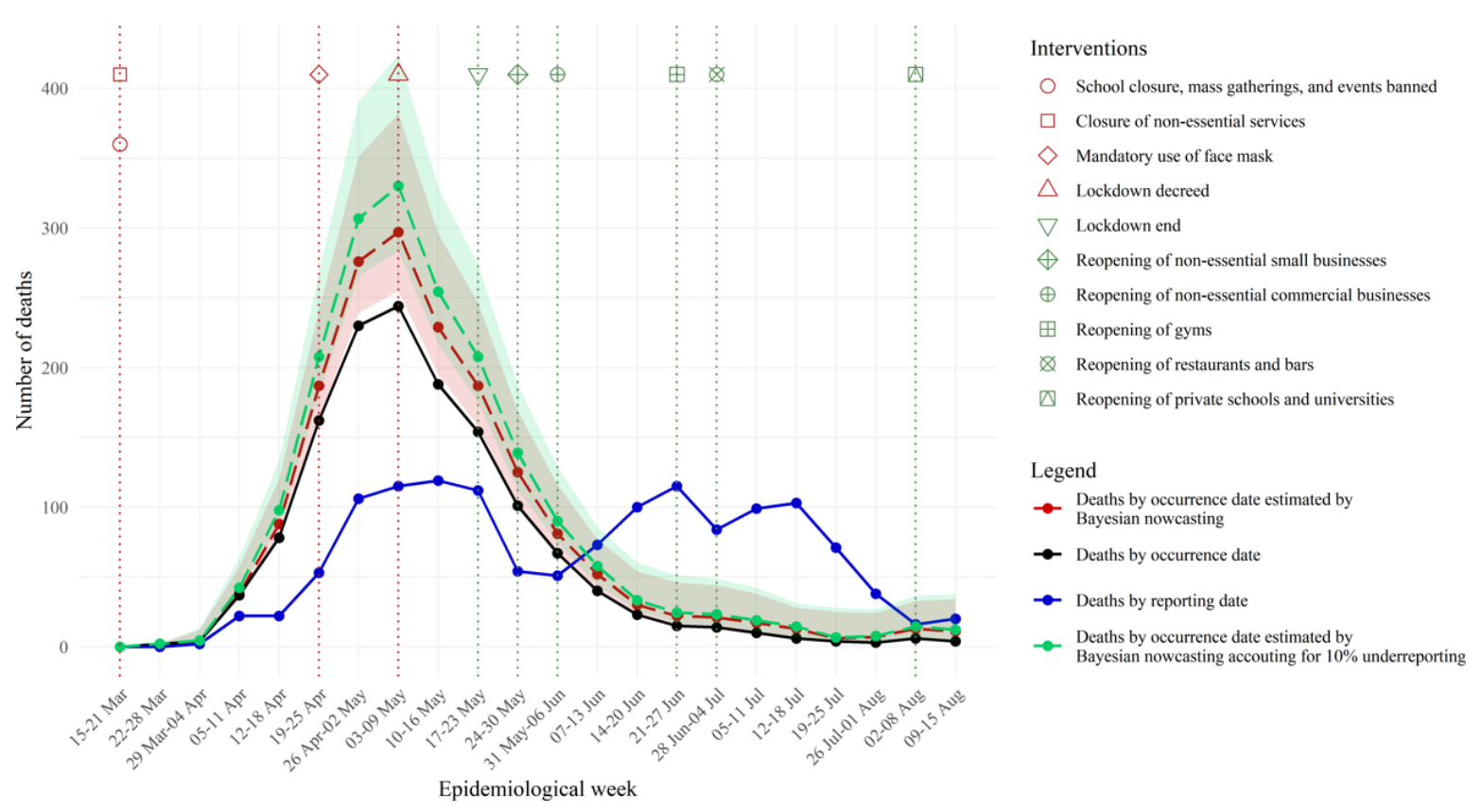

